\title{
ПРОБЛЕМЫ И ПЕРСПЕКТИВЫ НАЛОГООБЛОЖЕНИЯ МАЛОГО БИЗНЕСА В УКРАИНЕ
}

\begin{abstract}
Ю.Б. Иванов, Е.В. Тур*
На основе анализа современных тенденций динамики развития малого бизнеса в Украине предложен двухэтапный сценарий его налогового регулирования. Обоснован перспективный инструментарий налогового стимулирования развития малого бизнеса на примере налога на прибыль предприятий.
\end{abstract}

Ключевые слова: малый бизнес, система налогообложения, налоговое стимулирование, налоговая скидка.

JEL-классификация: H25, L26.

DOI: $10.46782 / 1818-4510-2021-2-14-26$

Материал поступил 21.04.2021 2.

В украинской экономике все более значительную роль играет малый бизнес. Предприятия с небольшой численностью работающих отличаются гибкостью и способностью приспосабливаться к текущим условиям, влияющим на обеспечение устойчивости экономики страны. Малые предприятия более ориентированы на конечного потребителя и успешно занимают сегмент, который не входит в группу интересов крупных предприятий. Кроме того, малый бизнес играет важную социальную роль, предоставляя рабочие места для значительной части населения.

Осуществление экономических реформ и становление рыночных отношений во многом зависят от развития малого бизнеса, который является составляющей конкурентоспособности экономики. Без поддержки малых предприятий невозможно обеспечить эффективное функционирование экономики, многообразие и равноправие форм собственности и хозяйствования.

\section{Тенденции развития малого бизнеса в Украине в 2010-2018 г2.}

В 2018 г. в Украине количество крупных предприятий составляло 446 единиц
(0,02\% от общего количества субъектов хозяйствования), 99,98\% приходилось на 16057 средних предприятий, 46602 малых и 292772 микропредприятия. По сравнению с 2010 г. наблюдалась тенденция уменьшения количества работающих предприятий. Количество крупных предприятий сократилось на 24\%, средних - на 23\% в 2018 г. по сравнению с 2010 г., малых и микропредприятий - на 18 и 3\% соответственно. В 2010-2018 гг. малые предприятия составляли $13-15 \%$ от общего количества предприятий, а микропредприятия 79-82\%. Изменения в количестве малых и микропредприятий могут быть обусловлены уменьшением объема реализации и девальвацией гривны в 2014-2015 гг. В 2018 г. по сравнению с 2015 г. наблюдался рост числа малых и микропредприятий (табл. 1).

Если анализировать динамику количества различных видов предприятий в странах ЕC за аналогичный период, то можно сказать, что число крупных предприятий увеличилось на $9 \%$, средних - на $7 \%$, малых и микропредприятий - на 6 и 21\% соответственно. В 2018 г. количество крупных предприятий составляло $0,19 \%$, средних - 0,94, малых

* Иванов Юрий Борисович (yuriy.ivanov.ua@gmail.com), доктор экономических наук, профессор, Научно-исследовательский центр индустриальных проблем развития НАН Украины (г. Харьков, Украина);

Тур Елена Васильевна (ellenn@ukr.net), кандидат экономических наук, Научно-исследовательский центр индустриальных проблем развития НАН Украины (г. Харьков, Украина). 
Количество предприятий с распределением на большие, средние, малые и микропредприятия, 2010-2018 гг.

\begin{tabular}{|c|c|c|c|c|c|c|c|c|c|}
\hline Год & Всего & Крупные & $\begin{array}{c}\text { \% от } \\
\text { общего } \\
\text { коли- } \\
\text { чества }\end{array}$ & Средние & $\begin{array}{c}\text { \% от } \\
\text { общего } \\
\text { коли- } \\
\text { чества }\end{array}$ & $\begin{array}{c}\text { Малые } \\
\text { (без } \\
\text { микро) }\end{array}$ & $\begin{array}{c}\text { \% от } \\
\text { общего } \\
\text { коли- } \\
\text { чества }\end{array}$ & Микро & $\begin{array}{c}\text { \% от } \\
\text { общего } \\
\text { коли- } \\
\text { чества }\end{array}$ \\
\hline 2010 & 378810 & 586 & 0,15 & 20983 & 5,54 & 56796 & 14,99 & 300445 & 79,31 \\
\hline 2011 & 375695 & 659 & 0,18 & 20753 & 5,52 & 58468 & 15,56 & 295815 & 78,74 \\
\hline 2012 & 364935 & 698 & 0,19 & 20189 & 5,53 & 57587 & 15,78 & 286461 & 78,50 \\
\hline 2013 & 393327 & 659 & 0,17 & 18859 & 4,79 & 55332 & 14,07 & 318477 & 80,97 \\
\hline 2014 & 341001 & 497 & 0,15 & 15906 & 4,66 & 45676 & 13,39 & 278922 & 81,80 \\
\hline 2015 & 343440 & 423 & 0,12 & 15203 & 4,43 & 43573 & 12,69 & 284241 & 82,76 \\
\hline 2016 & 306369 & 383 & 0,13 & 14832 & 4,84 & 43459 & 14,19 & 247695 & 80,85 \\
\hline 2017 & 338256 & 399 & 0,12 & 14937 & 4,42 & 44818 & 13,25 & 278102 & 82,22 \\
\hline 2018 & 355877 & 446 & 0,13 & 16057 & 4,51 & 46602 & 13,09 & 292772 & 82,27 \\
\hline
\end{tabular}

Источник. Государственная служба статистики Украины. Развитие предпринимательства. URL: http:// www.ukrstat.gov.ua/operativ/menu/menu_u/sze_20.htm

- 5,87 и микропредприятий - 93\% от их общего числа. То есть для ЕС было характерно большее количество микропредприятий, чем для Украины, на 10\%, но меньшее количество малых и средних предприятий - на 8 и 3,5\% соответственно. Это может быть обусловлено европейскими формами поддержки предпринимателей, предоставляющих благоприятные условия для начала бизнеса, например наличием льготного кредитования и субсидирования процентных ставок.

Анализ объемов реализованной продукции (товаров, услуг) свидетельствует, что в 2010-2018 гг. доля реализованной продукции выросла на 1,1\% по микропредприятиям и на 1,2\% по малым предприятиям (рис. 1). Доля крупных предприятий составляла в 2018 г. 38,2\% от общего количества реализованной продукции, на долю средних предприятий приходилось $42,6 \%$, малых и микропредприятий - 12,7 и $6,5 \%$ соответственно.

Следовательно объем реализованной продукции малых и микропредприятий увеличился за 2010-2018 гг. на 2\% и составлял 19\%. Это может быть связано с увеличением физического объема продаж и ростом цен на продукцию. Следует отметить, что в 2018 г. объем реализованной продукции европейских малых и микропредприятий составлял 38,4\% (на 19\% больше, чем в Украине).

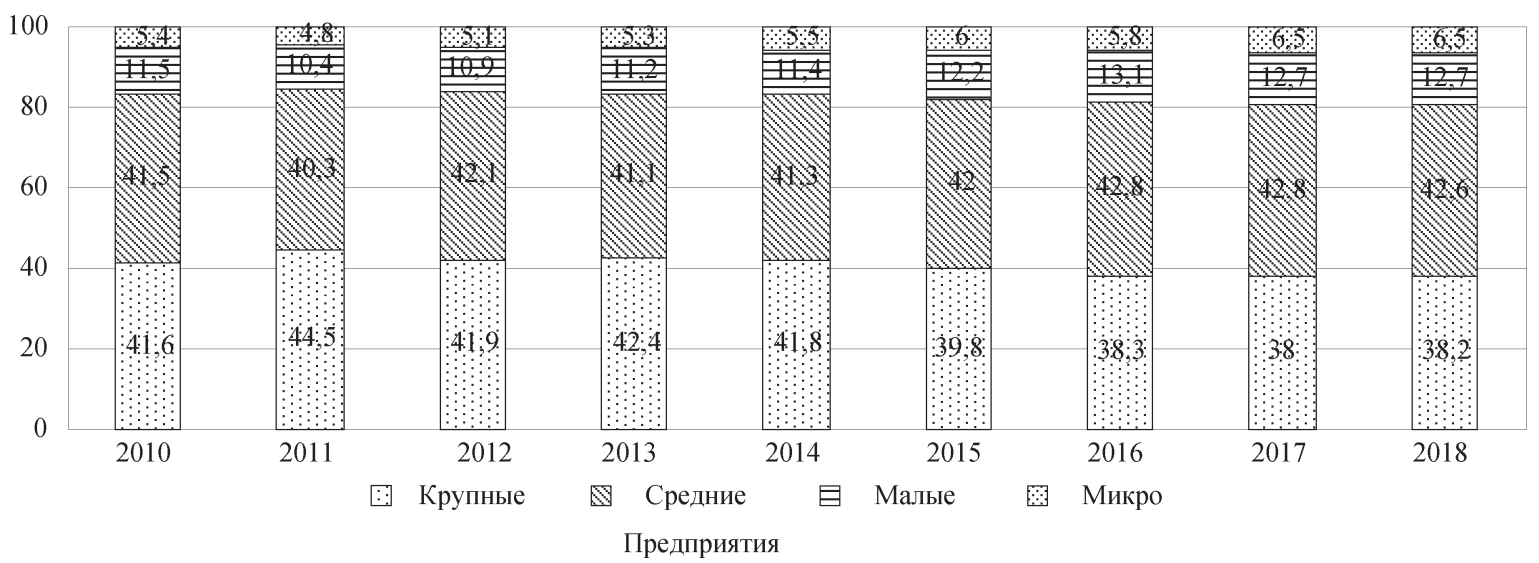

Рис. 1. Распределение объема реализованной продукции по разным видам предприятий, 2010-2018 гг., \%

Источник. Государственная служба статистики Украины. Развитие предпринимательства. URL: http:// www.ukrstat.gov.ua/operativ/menu/menu_u/sze_20.htm 
Анализ динамики малых предприятий по видам деятельности свидетельствует о том, что в 2010-2018 гг. происходило сокращение общего числа малых предприятий. С 2010 по 2018 г. количество предприятий уменьшилось на 5\%. Что касается видов деятельности, то доля малых предприятий в оптовой и розничной торговле, ремонте автотранспортных средств и мотоциклов составляла 26-27\%, сельском, лесном и рыбном хозяйстве - 14, промышленности - 11, операциях с недвижимым имуществом - 10, строительстве $-8 \%$ (табл. 2).

Анализ удельного веса объемов реализованной продукции малых предприятий в общем объеме реализованной продукции и удельного веса малых предприятий в их общем количестве по видам экономической деятельности демонстрирует значительное превышение данных показателей по оптовой и розничной торговле; ремонту автотранспортных средств и мотоциклов (48,36 и 26,65\% соответственно) (рис. 2).

В сельском хозяйстве аналогичные показатели составляли 14,2 и 11,22\%, для промышленности - 12,89 и 11,59\%.

Проведенный за аналогичный период анализ удельного веса объемов реализованной продукции малых предприятий и удельного веса количества предприятий по видам экономической деятельности стран EC также свидетельствует о наибольшем присутствии представителей малого бизнеса в оптовой и розничной торговле, ремонте

Таблица 2

Динамика количества малых предприятий в Украине и их распределение по видам экономической деятельности

\begin{tabular}{|c|c|c|c|c|c|c|}
\hline \multirow[b]{2}{*}{ Вид экономической деятельности } & \multicolumn{2}{|c|}{2010 г. } & \multicolumn{2}{|c|}{2014 г. } & \multicolumn{2}{|c|}{2018 г. } \\
\hline & Единиц & $\begin{array}{c}\% \text { от } \\
\text { общего } \\
\text { количества }\end{array} \mid$ & Единиц & $\begin{array}{c}\% \text { от } \\
\text { общего } \\
\text { количества }\end{array} \mid$ & Единиц & $\begin{array}{c}\% \text { от } \\
\text { общего } \\
\text { количества }\end{array}$ \\
\hline Всего & 357241 & 100,00 & 324598 & 100,00 & 339374 & 100,00 \\
\hline $\begin{array}{l}\text { В том числе: } \\
\text { сельское, лесное и рыбное } \\
\text { хозяйство }\end{array}$ & 47213 & 13,22 & 43389 & 13,37 & 48183 & 14,20 \\
\hline промышленность & 41373 & 11,58 & 37107 & 11,43 & 39322 & 11,59 \\
\hline строительство & 36706 & 10,27 & 28851 & 8,89 & 28719 & 8,46 \\
\hline $\begin{array}{l}\text { оптовая и розничная торговля; } \\
\text { ремонт автотранспортных средств } \\
\text { и мотоциклов }\end{array}$ & 105898 & 29,64 & 90842 & 27,99 & 90432 & 26,65 \\
\hline $\begin{array}{l}\text { транспорт, складское хозяйство, } \\
\text { почтовая и курьерская } \\
\text { деятельность }\end{array}$ & 12330 & 3,45 & 13757 & 4,24 & 14939 & 4,40 \\
\hline $\begin{array}{l}\text { временное размещение } \\
\text { и организация питания }\end{array}$ & 9353 & 2,62 & 7593 & 2,34 & 7272 & 2,14 \\
\hline информация и телекоммуникации & 12771 & 3,57 & 12939 & 3,99 & 14175 & 4,18 \\
\hline $\begin{array}{l}\text { финансовая и страховая } \\
\text { деятельность }\end{array}$ & 5254 & 1,47 & 4083 & 1,26 & 3790 & 1,12 \\
\hline $\begin{array}{l}\text { операции с недвижимым } \\
\text { имуществом }\end{array}$ & 26868 & 7,52 & 30719 & 9,46 & 35902 & 10,58 \\
\hline $\begin{array}{l}\text { профессиональная, научная } \\
\text { и техническая деятельность }\end{array}$ & 31246 & 8,75 & 29330 & 9,04 & 28150 & 8,29 \\
\hline $\begin{array}{l}\text { деятельность в сфере } \\
\text { административного } \\
\text { и вспомогательного обслуживания }\end{array}$ & 14959 & 4,19 & 14277 & 4,40 & 16444 & 4,85 \\
\hline образование & 2345 & 0,66 & 2023 & 0,62 & 2263 & 0,67 \\
\hline $\begin{array}{l}\text { здравоохранение и предоставление } \\
\text { социальной помощи }\end{array}$ & 4390 & 1,23 & 3889 & 1,20 & 4431 & 1,31 \\
\hline $\begin{array}{l}\text { искусство, спорт, развлечения } \\
\text { и отдых }\end{array}$ & 1969 & 0,55 & 1847 & 0,57 & 2031 & 0,60 \\
\hline предоставление других видов услуг & 4566 & 1,28 & 3952 & 1,22 & 3321 & 0,98 \\
\hline
\end{tabular}

Источник. Государственная служба статистики Украины. Развитие предпринимательства. URL: http:// www.ukrstat.gov.ua/operativ/menu/menu_u/sze_20.htm 
Проблемы и перспективы налогообложения малого бизнеса в Украине

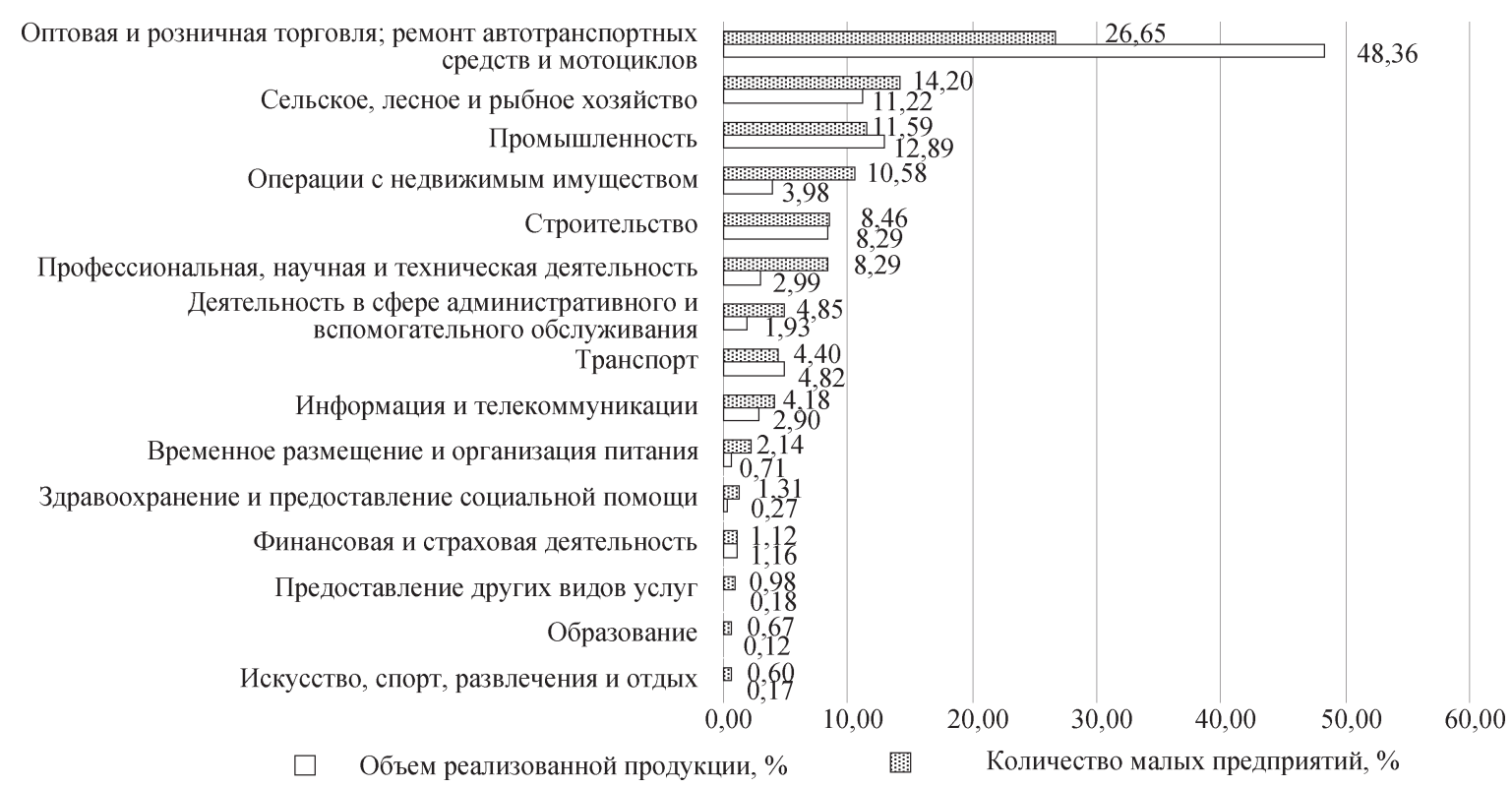

Рис. 2. Объем реализованной продукции малых предприятий и их количество, 2018 г., \% к общим показателям по видам экономической деятельности

Источник. Государственная служба статистики Украины. Развитие предпринимательства. URL: http:// www.ukrstat.gov.ua/operativ/menu/menu_u/sze_20.htm

автотранспортных средств и мотоциклов (47,4 и 27,34\% соответственно) (рис. 3 ).

В 2018 г. предприятия оптовой и розничной торговли, по ремонту автотранспортных средств и мотоциклов, сельского, лесного и рыбного хозяйства, в сфере операций с недвижимым имуществом имели самый высокий уровень рентабельности операционной деятельности - 20,3, 18,6 и 11,6\% соответственно. Наиболее убыточными оказались предприятия, занимающиеся финансовой и страховой деятельностью, а также деятельно-

Предоставление других видов услуг

Искусство, спорт, развлечения и отдых

Здравоохранение и предоставление социальной помощи

Образование

Деятельность в сфере административного и вспомогательного обслуживания

Профессиональная, научная и техническая деятельность

Операции с недвижимым имуществом

Финансовая и страховая деятельность

Информация и телекоммуникации

Временное размещение и организация питания

Транспорт, складское хозяйство, почтовая и курьерская деятельность

Оптовая и розничная торговля; ремонт автотранспортных средств и мотоциклов Строительство

Промышленность

Сельское, лесное и рыбное хозяйство

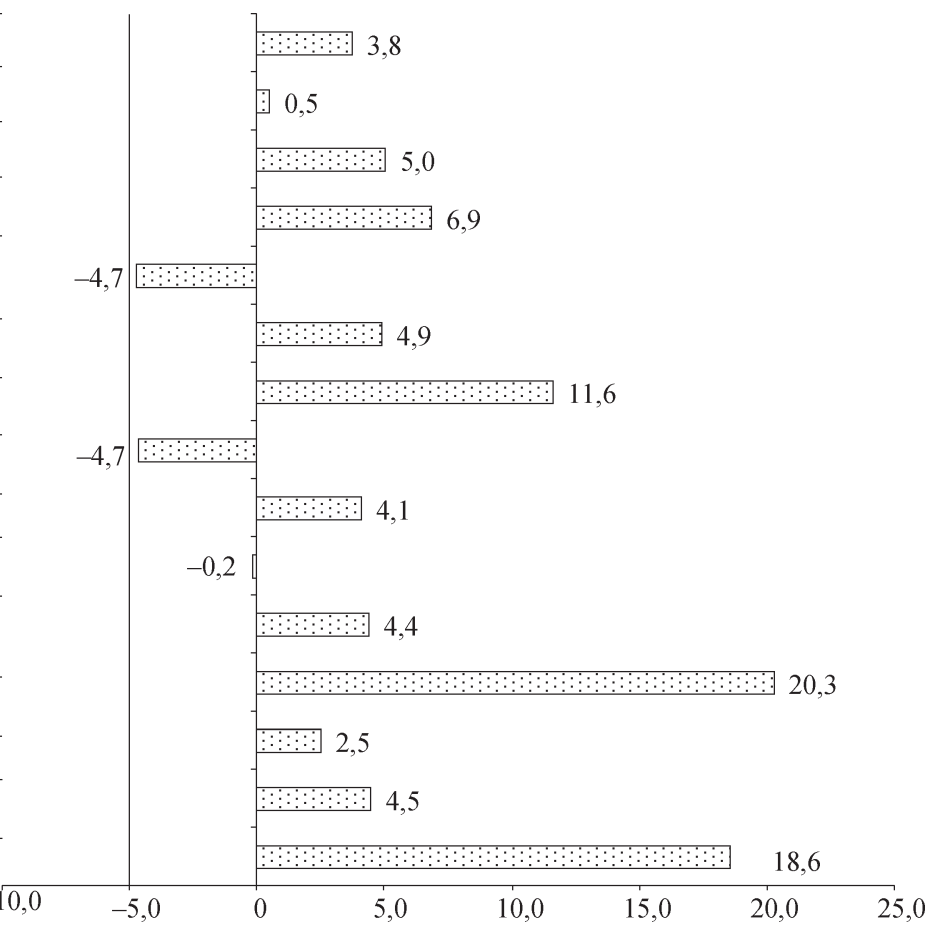

Рис. 3. Уровень рентабельности (убыточности) операционной деятельности малых предприятий по видам деятельности, 2018 г., \%

Источник. Государственная служба статистики Украины. Развитие предпринимательства. URL: http:// www.ukrstat.gov.ua/operativ/menu/menu_u/sze_20.htm 
стью в сфере административного и вспомогательного обслуживания (-4,7\%). Низкая рентабельность страховой деятельности могла быть обусловлена ростом страховых случаев, доминированием ценовой, а не сервисной конкуренции. Высокая рентабельность могла быть следствием наличия низкой себестоимости товаров, широкого ассортимента, большого объема продаж. Аутсайдеры оптовой и розничной торговли по показателю рентабельности представлены на рис. 4.

В группу аутсайдеров попали розничная торговля коврами, ковровыми изделиями, покрытием для стен и пола в специализированных магазинах и розничная торговля в специализированных магазинах электронной аппаратурой бытового назначения для приема, записи, воспроизведения звука и изображения со значением рентабельности -32,1 и -28\% соответственно. Возможными причинами такого положения могли быть непосредственная связь с курсом валют, низкая оборачиваемость товарных запасов или неучтенная выручка, а также уклонение от налогообложения.

По данным Минэкономразвития, теневая экономика в 2018 г. в Украине составляла $30 \%$ от объема официального ВВП (рис. 5).

Наблюдалась определенная взаимосвязь показателей уровня теневой экономики и рентабельности малых предприятий: чем больше уровень теневой экономики, тем меньше рентабельность. Так, в 2014 г. теневая экономика составляла 43\% от объема официального ВВП, рентабельность - 17,9\%. В 2018 г., когда уровень теневой экономики понизился (30\%), рентабельность была 8,3\% (наибольший показатель за 8 лет). Некоторые малые предприятия осуществляют свою деятельность без государственной регистрации и постановки на налоговый учет. Также бывают случаи, когда предприятия регистрируются в начале отчетного периода, затем прекращают свою деятельность до начала следующего и не платят налоги. Наличие теневой экономики приобретает масштабы системной проблемы, поскольку тормозит раскрытие и использование предпринимательского потенциала (Чернявский, Некрасов, Титко, 2017).

В 2018 г. малый бизнес обеспечивал занятость каждого пятого работающего на предприятиях в Украине. В то же время в странах ЕС в этом секторе занято около $50 \%$ экономически активного населения. Стабильная численность работающих в малом бизнесе объясняется спросом на новые кадры, предоставлением более выгодных условий работы, чем на крупных предприятиях, например гибкого графика, высокой заработной платы и т. д. (табл. 3).

Анализ статистических данных свидетельствует о том, что в 2014 г. численность наемных работников в малом бизнесе резко уменьшилась, что связано с экономическим кризисом. Это отразилось на предпри-

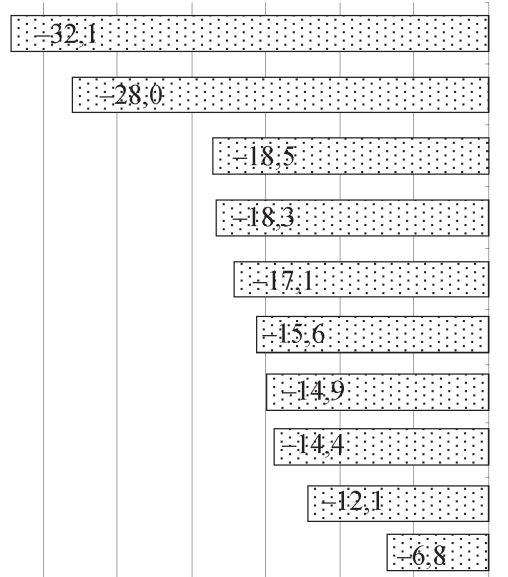

$-35,0-30,0-25,0-20,0-15,0-10,0-5,0 \quad 0$
Розничная торговля коврами, ковровыми изделиями, покрытием для стен и пола в специализированных магазинах Розничная торговля в специализированных магазинах электронной аппаратурой бытового назначения для приема, записи, воспроизведения звука и изображения Розничная торговля телекоммуникационным оборудованием в специализированных магазинах Розничная торговля рыбой, ракообразными и моллюсками в специализированных магазинах Оптовая торговля табачными изделиями

Деятельность посредников в торговле одеждой, мехом, обувью и кожаными изделиями

Розничная торговля одеждой в специализированных магазинах

Деятельность посредников в торговле топливом, рудами, металлами и промышленными химическими веществами Оптовая торговля сельскохозяйственным сырьем и живыми животными Розничная торговля с лотков и на рынках одеждой и обувью

Рис. 4. Наименее рентабельные группы оптовой и розничной торговли малых предприятий, 2018 г., \%

Источник. Государственная служба статистики Украины. Развитие предпринимательства. URL: http:// www.ukrstat.gov.ua/operativ/menu/menu_u/sze_20.htm 
Проблемы и перспективы налогообложения малого бизнеса в Украине

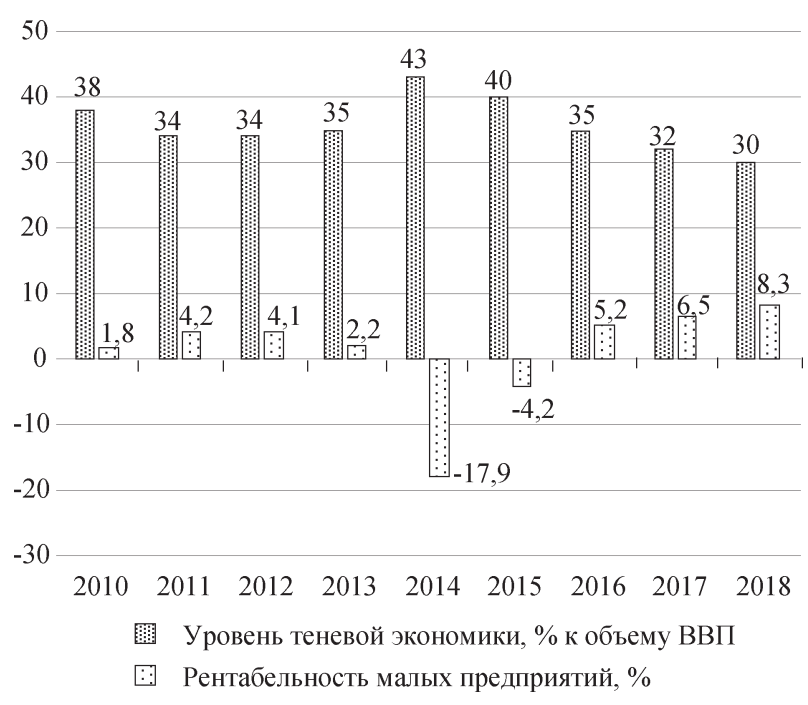

Рис. 5. Уровни теневой экономики в Украине и рентабельности (убыточности) операционной деятельности малых предприятий, 2010-2018 гг., \%

Источник. Министерство развития экономики, торговли и сельского хозяйства Украины. URL: https:/ /www.me.gov.ua/

ятиях всех размеров. Основные финансовые показатели малых предприятий изображены на рис. 6.

По результатам анализа финансовых показателей малых предприятий в 20132018 гг. можно сделать вывод, что собственный капитал уменьшился на 13\%. Внеоборотные активы постепенно росли, что может быть обусловлено приобретением имущества или инвестициями в строительство. Величина оборотных активов после резкого увеличения в 2016 г. снизилась, но по сравнению с 2013 г. она значительно возросла, что свидетельствует о росте кредитов, несмотря на стабильное значение размера собственного капитала. Текущие обязательства имели устойчивую тенденцию роста, особенно в 2016 г., что говорит об увеличении краткосрочных долговых обязательств малых предприятий.

Проведенный анализ тенденций развития малого бизнеса в Украине в 2010-

Таблица 3

Количество наемных работников на малых предприятиях Украины по видам экономической деятельности

\begin{tabular}{|l|r|c|c|c|c|c|}
\hline \multicolumn{1}{|c|}{$\begin{array}{c}\text { Вид экономической } \\
\text { деятельности }\end{array}$} & \multicolumn{2}{|c|}{2010 г. } & \multicolumn{2}{|c|}{2014 г. } & \multicolumn{2}{c|}{2018 гт } \\
\cline { 2 - 6 } & Единиц & $\begin{array}{c}\text { \%бщего } \\
\text { коли- } \\
\text { чества }\end{array}$ & Единиц & $\begin{array}{c}\text { общего } \\
\text { коли- } \\
\text { чества }\end{array}$ & $\begin{array}{c}\text { Единиц } \\
\text { коли- } \\
\text { чества }\end{array}$ \\
\hline Всего & 2043,7 & 26,1 & 1583,0 & 25,6 & 1553,8 & 26,5 \\
\hline $\begin{array}{l}\text { В том числе: } \\
\text { сельское, лесное и рыбное хозяйство }\end{array}$ & 176,5 & 24,4 & 185,6 & 31,1 & 189,4 & 34,7 \\
\hline промышленность & 351,4 & 11,4 & 276,8 & 11,4 & 290,0 & 13,8 \\
\hline строительство & 240,9 & 52,1 & 144,5 & 52,0 & 152,0 & 56,7 \\
\hline $\begin{array}{l}\text { оптовая и розничная торговля; ремонт } \\
\text { автотранспортных средств и мотоциклов }\end{array}$ & 523,6 & 43,1 & 371,4 & 37,4 & 360,6 & 35,4 \\
\hline $\begin{array}{l}\text { транспорт, складское хозяйство, почтовая } \\
\text { и курьерская деятельность }\end{array}$ & 95,3 & 10,3 & 91,8 & 12,1 & 92,3 & 12,1 \\
\hline $\begin{array}{l}\text { временное размещение и организация } \\
\text { питания }\end{array}$ & 67,0 & 50,7 & 44,0 & 44,3 & 43,7 & 44,9 \\
\hline информация и телекоммуникации & 76,7 & 33,2 & 65,8 & 34,7 & 63,8 & 41,2 \\
\hline финансовая и страховая деятельность & 25,2 & 31,2 & 18,0 & 29,6 & 16,4 & 22,6 \\
\hline операции с недвижимым имуществом & 147,5 & 62,9 & 115,0 & 70,0 & 117,8 & 72,3 \\
\hline $\begin{array}{l}\text { профессиональная, научная } \\
\text { и техническая деятельность }\end{array}$ & 146,0 & 49,8 & 110,4 & 49,2 & 92,5 & 50,9 \\
\hline $\begin{array}{l}\text { деятельность в сфере административного } \\
\text { и вспомогательного обслуживания }\end{array}$ & 103,7 & 39,8 & 89,3 & 33,4 & 75,5 & 35,2 \\
\hline образование & 16,7 & 47,6 & 11,8 & 58,9 & 10,6 & 63,5 \\
\hline $\begin{array}{l}\text { здравоохранение и предоставление } \\
\text { социальной помощи }\end{array}$ & 32,4 & 35,9 & 31,5 & 47,1 & 27,9 & 11,9 \\
\hline искусство, спорт, развлечения и отдых & 9,8 & 34,9 & 8,0 & 26,2 & 9,6 & 36,9 \\
\hline предоставление других видов услуг & 31,0 & 74,7 & 19,1 & 77,8 & 11,7 & 72,3 \\
\hline
\end{tabular}

Источник. Государственная служба статистики Украины. Развитие предпринимательства. URL: http:// www.ukrstat.gov.ua/operativ/menu/menu_u/sze_20.htm 


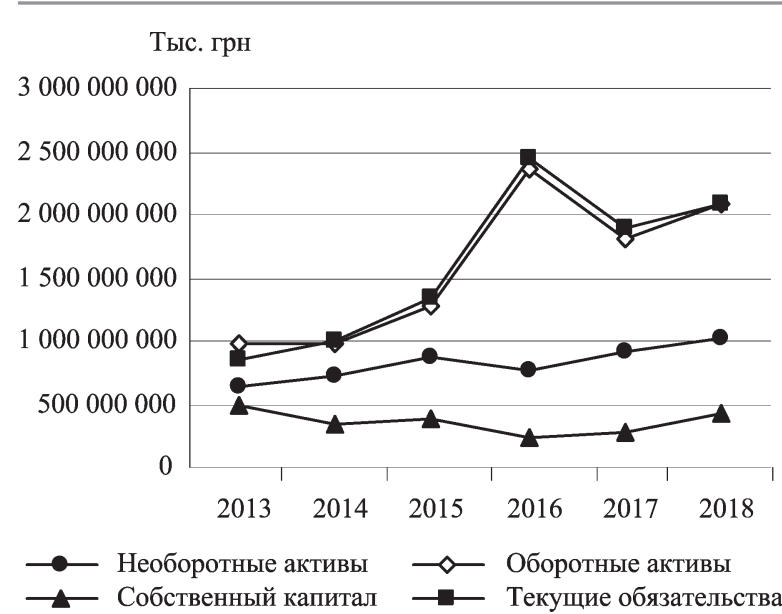

Рис. 6. Основные финансовые показатели малых предприятий, 2013-2018 гг.

Источник. Государственная служба статистики Украины. развитие предпринимательства. URL: http:/ /www.ukrstat.gov.ua/operativ/menu/menu_usze_20.htm

2018 гг. свидетельствует о наличии возможностей его успешного функционирования, главным условием которого является государственная поддержка. Как показывает практика, данный сегмент бизнеса наиболее распространен в видах экономической деятельности, не требующих крупных финансовых вложений. Это подтверждается статистическими данными, согласно которым в 2010-2018 гг. оптовая и розничная торговля была лидером по показателю количества малых предприятий и объему peализованной продукции.

Уровень рентабельности малых предприятий в 2018 г. вырос на 6,5\% по сравнению с 2010 г. и составил в среднем 8,3\%. За аналогичный период наибольшая рентабельность была характерна для предприятий оптовой и розничной торговли - 20,3\%. Как показал анализ, возможными причинами, тормозящими дальнейший рост рентабельности, могут быть недостаток финансовых средств для модернизации оборудования, повышения квалификации кадров, внедрения новых технологий и др.

\section{Налоговая политика как инструмент стимулирования малого бизнеса}

Государственная поддержка и стимулирование развития малого бизнеса в любой стране, в том числе и в Украине, предусматривают широкий спектр различных инструментов государственного регулирования, среди которых особую роль играют средства налоговой политики. Налоговые инструменты - это достаточно действенное, но в то же время не исключительное средство государственной политики в сфере малого бизнеса. В настоящее время одной из первоочередных задач в Украине является переход от государственной поддержки к стимулированию развития малого бизнеса, что требует соответствующих изменений инструментария.

В современной налоговой науке существуют различные подходы к толкованию сущности понятий «налоговое стимулирование» и «налоговая поддержка». Первый из них основывается на отсутствии принципиального различия между этими понятиями, а разграничение связано исключительно со сферой применения соответствующего термина. Так Л. Тарангул (2012) употребляет эти дефиниции в таких словосочетаниях, как «бюджетная поддержка» и «налоговое стимулирование».

Другой подход заключается в различном толковании целей налоговой политики: поддержка направлена «на компенсацию негативных воздействий и обеспечение устойчивости предприятия в агрессивной внешней среде, а стимулирование - на создание налоговых условий для развития экономического агента» (Чечетова-Терашвілі, 2017). На наш взгляд, этот подход выглядит более приемлемым, а его использование позволяет идентифицировать перечень инструментов налогового регулирования, которые применяются для поддержания или для налогового стимулирования.

Проблемы налогового регулирования малого бизнеса всегда были в центре внимания украинских ученых ${ }^{1}$ (Виговська, 2009; Поліщук, Василевський, 2014; Соболева, Козаченко, Гулювата, 2018; Стрілець, 2019; Толмачова, Ляшенко, Колєснікова, 2017; Фролова, 2018; Чуприна, Юзовицька, 2019). Однако важным вопросом остается определение конкретных рекомендаций по реформированию налоговой системы Украины для содействия развитию малого бизнеса.

1 Варналій 3.С. 2008. Мале підприємництво: основи теорії $і$ практики. Київ: Т-во «Знання», КОО. 
Первый опыт налоговой поддержки малого бизнеса в нашей стране относится к 1991 г., когда еще в рамках законодательства СССР в конструкции налога на прибыль предприятий и организаций были предусмотрены несколько специальных механизмов (Иванов, 2010):

- налоговая скидка по ставке 100\% по прибыли, направленной малыми предприятиями на строительство, реконструкцию и обновление основных фондов, внедрение новой техники и технологии, подготовку и повышение квалификации кадров;

- двухлетние налоговые каникулы для вновь созданных малых предприятий по производству и переработке сельскохозяйственной продукции, производству товаров народного потребления, предприятий по производству строительных материалов, внедренческих предприятий (выручка от этих видов деятельности равна или превышает $70 \%$ );

- уменьшение ставки налога на прибыль от других видов деятельности малых предприятий: первый год работы - 25\%, второй год - $50 \%$ от установленного размера ставки.

В качестве страховочного механизма было предусмотрено, что при прекращении деятельности малого предприятия до истечения трехлетнего срока сумма налога исчисляется в полном размере за весь период его деятельности.

В течение первых лет независимости Украины налоговая поддержка субъектов малого бизнеса осуществлялась в рамках общей системы налогообложения с помощью налога на доходы и налога на прибыль предприятий. Наиболее радикальным шагом в области налоговой поддержки малого и среднего предпринимательства стало внедрение в 1999 г. Специального налогового режима, когда Указом Президента № 727/98 «Об упрощенной системе налогообложения, учета и отчетности субъектов малого предпринимательства» был введен единый налог, который за годы его существования подвергся существенным модификациям.

К существенным проблемам упрощенной системы налогообложения, на наш взгляд, относятся следующие:
- ограничение масштабов деятельности по группам сдерживает развитие и рост количественных показателей субъектов малого бизнеса;

- предельные размеры масштабов деятельности установлены в абсолютных величинах, что требует их периодического «ручного» пересмотра;

- необоснованным является применение различных социальных стандартов (минимальная заработная плата) для определения базы кратных ставок единого налога 1 и 2 групп плательщиков;

- органы местного самоуправления лишены права вводить налоговые льготы для третьей группы плательщиков единого налога;

- упрощенная система налогообложения не содержит действенных страховочных механизмов, противодействующих использованию плательщиками единого налога в схемах агрессивного налогового планирования крупных экономических агентов.

Альтернативой государственной налоговой политики в сфере малого бизнеса является использование инструментария общей системы налогообложения или специальных налоговых режимов (систем). Вместе с тем при реформировании налоговой системы следует также учитывать, что для Украины меры по уменьшению ставок основных налогов и существенному увеличению бюджетных расходов с целью стимулирования развития малого предпринимательства неприемлемы по ряду причин (Ногинова, 2014):

даже при стабильных экономических условиях в Украине ее социальные обязательства существенно превышают финансовые возможности;

снижение налоговых ставок как инструмент стимулирования инвестиций в условиях политической нестабильности Украины не обеспечит желаемых результатов, а лишь приведет к уменьшению и без того ограниченных финансовых возможностей бюджетов;

отсутствие источников финансирования бюджетного дефицита не будет способствовать увеличению расходов сверх полученных доходов.

Современное состояние малого предпринимательства в Украине свидетельству- 
ет о необходимости изменения форм реализации налоговой политики и постепенного перехода от налоговой поддержки малого бизнеса к стимулированию его развития. Несмотря на все недостатки и аргументы против упрощенной системы налогообложения, предлагается двухэтапный сценарий развития налогового регулирования малого бизнеса.

Первый этап включает частичное сохранение упрощенной системы при постепенной фискализации расчетов и восстановлении учета операций субъектов малого бизнеса в соответствии с требованиями законодательства 2 :

- обоснование приоритетных видов деятельности субъектов малого бизнеса;

- ограничение сферы применения упрощенной системы исключительно приоритетными видами деятельности;

- развитие системы налоговой поддержки субъектов малого бизнеса в рамках обычной системы налогообложения (налог на прибыль предприятий, НДФЛ, НДС и др.);

- расширение полномочий органов местного самоуправления по налоговому регулированию в сфере малого бизнеса;

- формирование действенной системы налогообложения самозанятых лиц.

На втором этапе предлагается построение системы стимулирования в пределах обычной системы налогообложения и от-

2 Проект Закона о внесении изменений в Закон Украины «О применении регистраторов расчетных операций в сфере торговли, общественного питания и услуг». URL: https:/ /zakon.rada.gov.ua/laws/show/265/95-\%D0\%B2\%D1\%80 каз от упрощенной системы налогообложения. На этом этапе выполняются следующие действия:

- переход на инструментарий налогового регулирования общей системы налогообложения для приоритетных видов деятельности малых предприятий;

- формирование направлений налогового стимулирования малых предприятий и разработка соответствующего инструментария;

- стимулирование занятости и создание новых рабочих мест;

- стимулирование наращивания масштабов деятельности и объемов реализации продукции;

- стимулирование обновления основных средств, роста и повышения качества материально-технической базы производства;

- стимулирование внедрения новых технологий и инновационной активности малых предприятий в приоритетных видах деятельности.

Рассмотрим перспективный инструментарий налогового стимулирования развития малого бизнеса на примере налога на прибыль предприятий (табл. 4).

Освобождение прибыли от налогообложения. В мировой практике одной из наиболее распространенных форм стимулирования выступает механизм налоговых каникул, т. е. установленный законом срок, в течение которого та или иная группа предприятий или фирм освобождается от уплаты налога. Налоговые каникулы активно используются в Китае, Ирландии, Израи-

\section{Перспективный инструментарий налогового стимулирования развития} малого бизнеса (налог на прибыль предприятий)

\begin{tabular}{|c|c|c|c|c|}
\hline Налоговый инструментарий & $\begin{array}{c}\text { Стимулирование } \\
\text { занятости }\end{array}$ & $\begin{array}{c}\text { Наращивание } \\
\text { масштабов } \\
\text { деятельности }\end{array}$ & $\begin{array}{c}\text { Обновление } \\
\text { основных } \\
\text { средств }\end{array}$ & $\begin{array}{c}\text { Стимулирование } \\
\text { внедрения новых } \\
\text { технологий } \\
\text { и инновационной } \\
\text { активности }\end{array}$ \\
\hline $\begin{array}{l}\text { Освобождение прибыли } \\
\text { от налогообложения }\end{array}$ & & + & & + \\
\hline Уменьшение ставки налога & & + & & \\
\hline $\begin{array}{l}\text { Шкалы ставок с элементами } \\
\text { регрессии }\end{array}$ & & + & & \\
\hline Ускоренная амортизация & & & + & + \\
\hline Налоговая скидка & + & & + & + \\
\hline Налоговый кредит & + & & & + \\
\hline
\end{tabular}

Источник. Авторская разработка. 
ле. Последствиями применения этого инструмента являются максимальное облегчение процесса наращивания масштабов деятельности и внедрение новых технологий и инновационной активности.

Уменьшение ставки налога. Снижение налоговой ставки на прибыль в малых предприятиях приводит к росту капитальных вложений и наращиванию масштабов деятельности, что становится дополнительным стимулом развития предпринимательской деятельности. По теории А. Лаффера, снижение высокой ставки активизирует предпринимательство, следовательно, ведет к росту налогооблагаемой базы и общего объема налоговых поступлений в бюджет. Вопрос о необходимости снижения ставки налога на прибыль предприятий в настоящее время является очень актуальным.

Шкаль ставок с элементами регрессии. Регрессивное налогообложение предусматривает снижение налоговых ставок по мере увеличения его базы. Использование такого метода установления ставок стимулирует налогоплательщика к увеличению налоговой базы. На макроэкономическом уровне применение регрессивных ставок в налогообложении доходов (прибыли) юридических лиц способствует экономическому росту, созданию дополнительных рабочих мест, концентрации капитала. Такой метод установления ставок стимулирует ускоренное экономическое развитие субъектов предпринимательской деятельности. Однако регрессивные ставки налогов приводят к диспропорции в налогообложении субъектов предпринимательской деятельности, поскольку налоговое бремя в большей степени перекладывается на низкорентабельные предприятия, что может привести к их убыточности и ликвидации. Тем не менее регрессивные ставки налога на прибыль корпораций все-таки применяются в мировой практике, правда, не в чистом виде, а в сочетании с прогрессивными (США и Великобритания).

Ускоренная амортизащия. Ценность ускоренной амортизации для хозяйствующих субъектов заключается в снижении налогооблагаемой прибыли и сокращении процесса возврата ранее авансированного капитала для замены старого оборудования новым. При этом используются различные нормы ускоренной амортизации - от 10 до 50\%. Однако самые распространенные ставки составляют в среднем 15-18\% (Штань, 2014).

Налоговая скидка. Обеспечивает снижение налоговой нагрузки на предприятия путем исключения из налогооблагаемой базы определенных видов расходов, как правило, в процентах к ним или к сумме налога. Право на получение налоговой скидки во многих странах закреплено законодательно и наступает автоматически после введения новой техники в эксплуатацию. Принципиальным моментом является установление периода, в течение которого сохраняется право на скидку, когда сумма, подлежащая вычету из налогооблагаемой прибыли в соответствующем налоговом периоде, меньше размера такой прибыли. Наиболее либеральным при использовании данного инструмента является законодательство Бельгии, где этот период не ограничен.

Налоговый кредит. Простой (объемный) налоговый кредит предусматривает уменьшение суммы налога на полную сумму целевых расходов или ее часть. Приростной налоговый кредит предусматривает уменьшение суммы налога на полную или частичную сумму прироста соответствующих расходов в отчетном периоде по отношению к установленной базе (например, среднегодовые фактические расходы прошлых периодов или среднеотраслевые затраты, приведенные к фактическому объему деятельности).

Простой налоговый кредит стимулирует любые расходы, которые осуществляются предприятием в выбранном направлении, а приростной - только увеличение этих расходов. Поэтому в мировой практике часто оба вида налогового кредита используются одновременно.

Среди рассмотренных налоговых инструментов наиболее применяемой в европейской практике налогообложения и перспективной для Украины является налоговая скидка. Этот вид льгот используется в Великобритании, Бельгии, Дании на основе объемных показателей, а в Австралии, Австрии и Венгрии - на комбинированной основе, т. е. с учетом и объемных показателей, и показателей прироста. Такой вид 
налогового инструментария способствует стимулированию занятости, обновлению основных средств и внедрению новых технологий и инновационной активности.

Следует отметить, что одной из важных задач является стимулирование инноваций. В наиболее развитых странах льготные налоговые режимы получили распространение для компаний, которые разрабатывают, внедряют или используют инновации. Преимуществами могут быть уменьшение налоговой базы, ставки корпоративного налога, суммы налога на полную или частичную сумму понесенных инновационных расходов инновационного характера (инновационно-инвестиционный налоговый кредит), применение ускоренной нормы амортизации. Например, во Франции для вновь созданных малых предприятий, работающих в сфере новейших технологий, установлены налоговые «каникулы» на пять лет, в Канаде им предоставляется налоговый кредит на инвестиции в НИОКР (30\%), а применение единой ставки налога на прибыль корпораций в размере $12 \%$ позволяет стимулировать развитие малого бизнеса в наукоемких сферах экономики (Молдаван, 2014).

По нашему мнению, интересным и привлекательным для заимствования является опыт налогообложения малого бизнеса таких стран, как Франция, США и Эстония. Общая черта этой сферы для малых предприятий - предоставление налоговых льгот при условии реинвестирования определенной части прибыли в собственное развитие. Так, во Франции обязательным требованием применения упрощенного режима налогообложения является то, что предприятие реинвестирует часть прибыли в свою деятельность и обязуется ежегодно в течение следующих трех лет реинвестировать ту же долю прибыли, которая остается после уплаты налогов. В Эстонии же налогообложению подлежит только та прибыль, которая распределяется между участниками. То есть, если предприятие полностью реинвестирует свою прибыль в деятельность, налог на прибыль не уплачивается. В США на уровне штатов физические и юридические лица также обязаны вносить определенные платежи за свой доход. В настоящее время в некоторых штатах США ставки корпоративного налога изменились и могут быть фиксированными. Систематически пересматривается налоговое законодательство, что позитивно влияет на предпринимательскую деятельность.

Таким образом, на основе анализа состояния малого бизнеса в Украине предложен двухэтапный сценарий развития налогового регулирования его развития, последним этапом которого является отмена упрощенной системы налогообложения и построение системы стимулирования в пределах обычной системы налогообложения. Также обоснован перспективный инструментарий налогового стимулирования развития малого бизнеса на примере налога на прибыль предприятий, оценка которого показала, что применение налоговой скидки является наиболее эффективным налоговым инструментом, поскольку будет способствовать наращиванию масштабов деятельности, стимулированию занятости, обновлению основных средств, внедрению новых технологий и инновационной активности малых предприятий.

\section{СПИСОК ЛИТЕРАТУРЫ (REFERENCES)}

Виговська В.В. 2009. Малий бізнес України: сучасний стан і тенденції розвитку. Актуальні проблеми економіки. № 1. C 59-64. [Vyhovska V.V. 2009. Small business of Ukraine: modern state and development tendencies. Aktualni problemy ekonomiky. No 1. PP. 59-64. (In Ukr.)]

Іванов Ю.Б., Майбуров І.А. (Ред.). 2010. Бюджетна політика: теорія, методологія, інструментарій. Харків: ІНЖЕК. 492 с. [Ivanov Yu.B., Maiburov I.A. (Eds.). 2010. Tax policy: theory, methodology, tools. Kharkiv: INZhEK. 492 p. (In Ukr.)]

Молдован О.О. 2014. Стратегія реформування системи державних фінансів Украйни: завдання, пріоритети, механізми. Київ: НІСД. [Moldovan O.O. 2014. Strategy for reforming the public finance system of Ukraine: tasks, priorities, mechanisms. Kiev: NISD. (In Ukr.)]

Ногінова Н.M. 2014. Оподаткування малого підприємництва в Україні: сучасний стан та перспективи розвитку. Науковий вісник НЛТУ У $_{\text {- }}$ райни. Вип. 24.1. С. 259-263. [Nohinova N.M. 2014. Taxation of small business in Ukraine: Current state and prospects. Naukovyi visnyk NLTU Ukrainy. No 24.1. PP. 25-263. (In Ukr.)] 
Поліщук О.В., Василевський В.О. 2014. Оподаткування малого бізнесу у провідних країнах світу. Науковий вісник Херсонського державного університету. Серія «Економічні науки». Вип. 7. Ч. 1. C. 133-136. [Polischuk O.V., Vasylevskyi V.O. 2014. Small business taxation in the leading countries of the world. Naukovyi visnyk Khersonskoho derzhavnoho universytetu. Seriia «Ekonomichni nauky». No 7. P. 1. PP. 133-136. (In Ukr.)]

Соболева І.В., Козаченко А.А., Гулювата А.С. 2018. Порівняльний аналіз практики обліку й оподаткування суб'єктів малого та мікропідприємництва в Україні та країнах СС. Економіка і суспільство. № 19. C. 1340-1344. [Soboleva I.V., Kozachenko A.A., Huliuvata A.C. 2018. Comparative analysis of the accounting and taxation practice of small and microenterprises in Ukraine and EU countries. Ekonomika i suspilstvo. No 9. PP. 1340-1344. (In Ukr.)]

Стрілець В. 2019. Реалізація законодавчих ініціатив у сфері державного забезпечення розвитку малого бізнесу: досвід ЄС. Науковий вісник Ужгородського національного університету. Серія: Міжнародні економічні відносини та світове господарство. Вип. 24. Ч. 3. С. 95-100. [Strilets V. 2019. Legislative initiatives implementation in the small business state support development area: EU experience. Naukovyi visnyk Uzhhorodskoho natsionalnoho universytetu. Seriia: Mizhnarodni ekonomichni vidnosyny ta svitove hospodarstvo. No 24 . P. 3. PP. 95-100. (In Ukr.)]

Тарангул Л.Л. (Ред.). 2012. Бюджетна підтримка та податкове стимулювання нащіональної економіки України. Ірпінь: Фенікс. [Taranhul L.L. (Eds.) 2012. Budget support and tax incentives in national economy of Ukraine. Irpin: Feniks. (In Ukr.)]

Толмачова Г.Ф., Ляшенко В.І., Колеснікова Г.В. 2017. Регулювання розвитку малого і середнього підприємництва: досвід зарубіжних країн для України. Економічний вісник Донбасу. № 1. С. 157185. [Tolmachova G.F., Lyashenko V.I., Kolesnikova G.V. 2017. Regulation of the small and medium-sized enterprises development: the experience of foreign countries for Ukraine. Ekonomichnyi visnyk Donbasu. No 1. PP. 157-185. (In Ukr.)]

Фролова Н.Л. 2018. Світовий досвід державної політики у сфері розвитку малого та середньо- го бізнесу. Вісник економіки транспорту і промисловості. № 61. С. 68-78. [Frolova N.L. World experience of state policy in small and medium business development area. 2018. Visnyk ekonomiky transportu $i$ promyslovosti. No 61. PP. 68-78. (In Ukr.)]

Чернявський С.С., Некрасов В.А., Титко A.B. 2017. Тіньова економіка в Україні: стан, тенденції, иляхи подолання. Київ: Національна академія внутрішніх справ. 152 с. [Cherniavskyi S.S., Nekra-sov V.A., Titko A.V. 2017. Shadow economy in Ukraine: state, trends, ways to overcome. Kiev: Natsional'na akademiya vnutrishnikh sprav. 152 p. (In Ukr.)]

Чечетова-Терашвілі T.M. 2017. Теорія і практика розвитку малого та середнього підприємництва в Украіні. Харків: ФОП Лібуркина Л.М. [Chechetova-Terashvili T.M. 2017. Theory and practice of small and medium entrepreneurship development in Ukraine. Kharkiv: FOP Liburkina L.M. (In Ukr.)]

Чуприна Л.В., Юзовицька С.А. 2019. Світовий досвід розвитку малого підприємництва та його використання в Україні. Інфраструктура ринку. Вип. 32. С. 264-270. [Chupryna L.V., Yuzovytska S.A. 2019. World experience of small business development and its use in Ukraine. Infrastruktura rynku. No 32. PP. 264270. (In Ukr.)]

Штань М.В. 2014. Податкові інструменти регулювання економіки України в умовах глобалізації. Міжнародні відносини. Серія Економічні науки. № 4. URL: http://journals.iir.kiev.ua/index.php/ ec_n/article/view/2458/2190 [Shtan M.V. 2014. Tax instruments for regulation Ukrainian economy in the context of globalization. Mizhnarodni vidnosyny. Seriia «Ekonomichni nauky». No 4 URL: http:// journals.iir.kiev.ua/index.php/ec_n/article/view/2458/ 2190 (In Ukr.)]

Ярова Н.В. 2009. Регулювання податкового навантаження як фактор активізації інвестиційно-інноваційної діяльності підприємства. Бізнес Інформ. № 5. C. 25-30. [Yarova N.V. 2009. Regulation of the tax burden as a factor in enhancing the investment and innovation activities of the enterprise. Biznes Inform. No 5. PP. 25-30. (In Ukr.)] 
In citation: Belorusskiy Ekonomicheskiy zhurnal. 2021. No 2. PP. 14-26.

Belarusian Economic Journal. 2021. No 2. PP. 14-26.

\title{
CHALLENGES AND OUTLOOKS IN OF SMALL BUSINESS TAXATION IN UKRAINE
}

\section{Yuriy Ivanov $^{1}$, Elena Tur ${ }^{1}$}

\author{
Author affiliation: ${ }^{1}$ Research Center for Industrial Problems of Development of NAS of Ukraine \\ (Kharkov, Ukraine). \\ Corresponding author: Yuriy Ivanov (yuriy.ivanov.ua@gmail.com).
}

ABSTRACT. The article suggests a two-stage scenario of tax regulation for small business by analyzing its current developments. It reasons applicable mechanisms to encourage small business advancement on the example of the company business tax.

KEYWORDS: small business, tax system, tax incentive, tax rebate.

JEL-code: H25, L26.

DOI: $10.46782 / 1818-4510-2021-2-14-26$

Received 21.04.2021 